\title{
COTTON VEGETATION INDICES UNDER DIFFENTENT CONTROL METHODS OF RAMULARIA LEAF SPOT
}

\author{
INDICES DE VEGETAÇÃO NO ALGODOEIRO SOB DIFERENTES FUNGICIDAS \\ DE CONTROLE DA MANCHA DA RAMULÁRIA
}

\author{
Luiz Marcel MARTINS'; Everton da Silva NEIRO'; Alfredo Ricere DIAS²; \\ Cassiano Garcia ROQUE'; Fabio Henrique Rojo BAIO'ㄹ ${ }^{1}$ Paulo Eduardo TEODORO ${ }^{1}$ \\ 1. Universidade Federal de Mato Grosso do Sul (UFMS), Chapadão do Sul, Mato Grosso do Sul, Brasil; 2. Fundação Chapadão, \\ Chapadão do Sul, Mato Grosso do Sul, Brasil. eduteodoro@hotmail.com
}

\begin{abstract}
This work aimed to correlate treatments using fungicides to different vegetation indices in response to effects caused by ramularia leaf spot (Ramularia areola). The experiment was carried out in the municipality of Chapadão do Sul, state of Mato Grosso do Sul, in the harvest 2016/2017, and consisted of a randomized blocks design, with 17 treatments and four replications. Data were obtained from the Sequoia 4.0 passive sensor and the Green Seeker LT 200 active sensor. From the information recorded by the sensors, nine vegetation indices were generated and compared with the area under the curve of disease progression, plant height, yield, and agronomic efficiency, in 17 different treatments of fungicide products. Treatments responded differently to the product applied. The SAVI index (Soil Adjusted Vegetation Index), obtained from the band in the red spectral range, presented higher correlation to AACPD, agronomic efficiency, and yield. The NDVI index (Normalized Difference Vegetation Index) had a higher correlation to plant height and SR (simple ratio), both using the wavelength in the red spectral range.
\end{abstract}

KEYWORDS: Gossypium hirsutum L. Cotton diseases. Remote sensing. Multispectral sensors.

\section{INTRODUCTION}

With the introduction of new technologies to agriculture, several questions have arisen regarding their use. Questions have been intensified with the improvement of these new technologies. For instance, vegetation indices have become increasingly more usual and accurate with the enhancement of image capture sensors.

Vegetation Indices are mathematical models developed from wavelengths or spectral bands (ZARCO-TEJADA et al., 2005). These indices aim to understand the canopy variables and serve as the basis for several remote sensing applications for crop management since they are correlated to several critical biophysical properties (AHAMED et al., 2011). Change in plant canopies reflectance depends mainly on the number of leaves and canopy architecture (PONZONI et al., 2012). Therefore, any modification of these variables, such as foliar diseases that cause defoliation, will influence the reflectance and the vegetation indices (FRENCH et al., 2015). They may also be useful in the differentiation between diseased and healthy plants and diseases quantification. This fact is due to physiological stress that manifests in plants by changes in the pigment composition balance, such as carotenoid, chlorophyll, and xanthophyll (GONZÁLEZ-DUGO; MATEOS, 2008; DEVADAS et al., 2009).
In cotton, due to the increase in its cultivated area in the Cerrado, new problems have emerged, particularly of phytosanitary nature (GALBIERI et al., 2015). Ramularia leaf spot (Ramularia areola), or white spot, is the primary cotton disease. This pathogen used to occur at the end of the crop cycle and was not a crucial phytosanitary problem. However, in recent years, it began to manifest earlier and cause premature defoliation, resulting in significant production losses (GIROTO et al., 2013). The high disease severity at the beginning of the reproductive plant cycle leads to premature plant defoliation and implies losses (SHIVANKAR; WANGIKAR, 1992).

Ramularia leaf spot causes defoliation and vegetation indices can be a useful tool to capture this difference in defoliation. Thus, this study aimed to evaluate vegetation indices, captured by active and passive sensors, in response to effects caused by ramularia under different treatments with fungicide products for cotton crop in the region of Chapadões.

\section{MATERIAL AND METHODS}

The experiment was carried out in the area belonging to the Agricultural Research Support Foundation of Chapadão, located at Rodovia BR 060, km 011, in the municipality of Chapadão do Sul, Mato Grosso do Sul (1841'33”S; 52 40’45”W and $840 \mathrm{~m}$ asl). Sowing was carried out on December 20, 2016, with a spacing of $0.9 \mathrm{~m}$ 
between rows and ten plants per meter. Seedling emergence occurred on December 27, 2016. The variety used was FM 975WS.

The experiment consisted of a randomized blocks design with 17 treatments and four replications. Each plot comprised four $6 \mathrm{~m}$ planting rows, totaling $21.6 \mathrm{~m}^{2}$. The two central rows were considered as the useful area for data collection, and the two outer rows and one meter of the edges were considered as the border.

Growth regulators were applied to the experimental area and pests were controlled based on the crop's needs. Cotton plants were cultivated under no-tillage system with soybean (harvest 15/16) and Urochloa ruziziensis (winter). Basic fertilization was applied with $400 \mathrm{~kg} \mathrm{ha}^{-1}$ in the formula $11-52-00$ (N-P-K) and $150 \mathrm{~kg} \mathrm{ha}^{-1}$ of $\mathrm{KCl}$ at pre-sowing. Topdressing consisted of $130 \mathrm{~kg} \mathrm{ha}^{-1}$ of urea, applied at 20,35, and 50 days after emergence, always maintaining the equality in these requirements for the whole experimental area. No significant damage by pest attack or nutritional deficiency was observed over the crop cycle.

Treatment 1 was considered as the control, without fungicide application. The remaining 16 treatments received sequential applications (Table 1), from two to 16 multisite action fungicides. Eight applications were performed with $\mathrm{CO}_{2}$, using a backpack sprayer XR11002 model, with six nozzles, spaced at $0.45 \mathrm{~m}$, with three bar pressure and an application rate of $150 \mathrm{~L} \mathrm{ha}^{-1}$. The first application occurred at the B1 phenological stage, on February 09,2017 , from the second to the last spacing, with a 14-day interval.

Table 1. Treatments and rates used to control ramularia leaf spot (Ramularia areola) in cotton.

\begin{tabular}{llll}
\hline Treatment & Active Ingredient & Concentration $\left(\mathrm{g} . \mathrm{i} \cdot \mathrm{a} \cdot \mathrm{kg}^{-1}\right)$ & Rate $\left(\mathrm{g} \cdot \mathrm{pc} \cdot \mathrm{ha}^{-1}\right)\left(\mathrm{mL} \cdot \mathrm{pc} \cdot \mathrm{ha}^{-1}\right)$ \\
\hline 1 & - & - & - \\
2 & Fentin Hydroxide & 400 & 500 \\
3 & Chlorotalonil & 720 & 1500 \\
4 & Chlorotalonil & 500 & 1500 \\
5 & Copper Sulfate & 610 & 750 \\
6 & Fluazinam & 500 & 1000 \\
7 & Mancozebe & 750 & 1500 \\
8 & Copper Oxychloride + Mancozebe & $300+440$ & 1500 \\
9 & Chlorotalonil & 850 & 1500 \\
10 & Chlorotalonil + Copper Oxychloride & $250+504$ & 1500 \\
11 & Chlorotalonil & 825 & 1500 \\
12 & Fenpropimorph & 750 & 600 \\
13 & Mancozebe & 800 & 1500 \\
14 & Chlorotalonil + Thiophanate-Methyl & $600+240$ & 1250 \\
15 & Copper Oxychloride & 588 & 1000 \\
16 & Copper Nitrate & 440 & 200 \\
17 & Piraclostrobin + Fluxapiroxade & $333+167$ & $300+500$ \\
\hline
\end{tabular}

Four severity evaluations for ramularia leaf spot were performed over the crop cycle. The diagrammatic scale proposed by Aquino et al. (2008) was used in the following days and phenological stages, respectively: 03/28/2017, F9; 04/11/2017, F19; 04/25/2017, F20; and 05/19/2017, C3. From these severity evaluations, data of the area under the disease progress curve (AUDPC) were taken, and afterward, the efficiency (EF) of each replication was calculated, adapting the formula proposed by Abbot (1925).

The experimental area was overflown at the height of $120 \mathrm{~m}$ on $05 / 17 / 2017$ by an unmanned aerial vehicle (UAV) eBee RTK model (senseFly Inc.) when the plant was at the C3 phenological stage. Images were captured with the Sequoia 4.0 passive sensor with $1280 \times 960$ resolution, in the
Green $(550 \mathrm{~nm})$, Red $(660 \mathrm{~nm})$, Red Edge $(735 \mathrm{~nm})$, and NIR $(790 \mathrm{~nm})$ bands. All images presented a spatial resolution of $0.23 \mathrm{~m}$, orthorectified with the Pix4D Mapper software, and subject to radiometric corrections. On 05/19/2017, data were also collected from the NDVI (Normalized Difference Vegetation Index) by a GreenSeeker LT 200 active sensor (Trimble Inc.), which emits light at the red $(660 \mathrm{~nm})$ and near-infrared $(770 \mathrm{~nm})$ wavelengths, automatically measuring the light reflected by the plant and calculating the NDVI GS, at an average height of $0.8 \mathrm{~m}$ from the plant canopy.

For the vegetation index data collection, ten plants were sampled within the useful area by the Green Seeker sensor and 10 pixels by the Sequoia sensor. The vegetation indices used in this study were: 
NDVI S (Normalized Difference Vegetation Index) (QI et al. 1994):

NIR - Red

$\overline{N I R+R e d}$

NDRE (Normalized Difference Red Edge index) (QI et al. 1994):

NIR - Red Edge

$\overline{N I R+R e d ~ E d g e}$

SAVI-R (Soil Adjusted Vegetation Index) (HUETE, 1988):

$$
\frac{N I R-R e d}{(N I R+\operatorname{Red}+L)} \times(1+L)
$$

SAVI-RE (Soil Adjusted Vegetation Index) using the Red Edge band (HUETE, 1988):

$\frac{N I R-\text { Red Edge }}{(N I R+\text { Red Edge }+L)} \times(1+L)$

For the L constant, the values of 0.25 (SAVI-R 1 and SAVI-RE 1) (high vegetation densities) and 0.50 (SAVI-R 2 e SAVI-RE 2) (medium vegetation densities) were used.

SR-R (Simple Ratio) (HUNSAKER et al., 2003):

NIR

$\overline{\text { Red }}$

SR-RE (Simple Ratio) using the Red Edge band (HUNSAKER et al., 2003):

\section{NIR}

Red Edge

Plant height $(\mathrm{PH})$ was evaluated using ten plants per plot and yield (YIE) was assessed by collecting all cotton lint in $3.33 \mathrm{~m}$ in the two central rows inside the useful plot area, considering a final stand of 9 plants $\mathrm{m}^{-1}$. The values were converted into arrobas ha ${ }^{-1}$ of cotton seed.

After the beginning of applications, the experimental area was monitored, and only on 03/06/17, the first symptoms of ramularia leaf spot were observed when the crop was at the F1 stage.

Data were subject to analysis of variance and means clustering by the Scott-Knott's test at 5\% probability. Subsequently, the Pearson's correlation analysis was performed, and results were expressed by the correlation network. Variables with positive correlation are linked by a green trace, while variables with negative correlation are linked by a red trace. Trace thickness is proportional to the magnitude of the correlation modulus. All analyses were performed using the Rbio software (BHERING, 2017).

\section{RESULTS AND DISCUSSION}

Treatments presented a great difference when the crop was at the $\mathrm{C} 3$ phenological stage. At this stage, plants already presented great defoliation in some treatments (such as 1,5 , and 10), whereas other treatments had practically no defoliation (such as 2, 3, and 4) (Figure 1). The defoliation was caused by the disease, which was already at the advanced attack stage, presenting a significant amount of disease in some plots and resulting in high scores, based on the diagrammatic scale proposed by Aquino et al. (2008). Therefore, images and reflections were collected at this time.

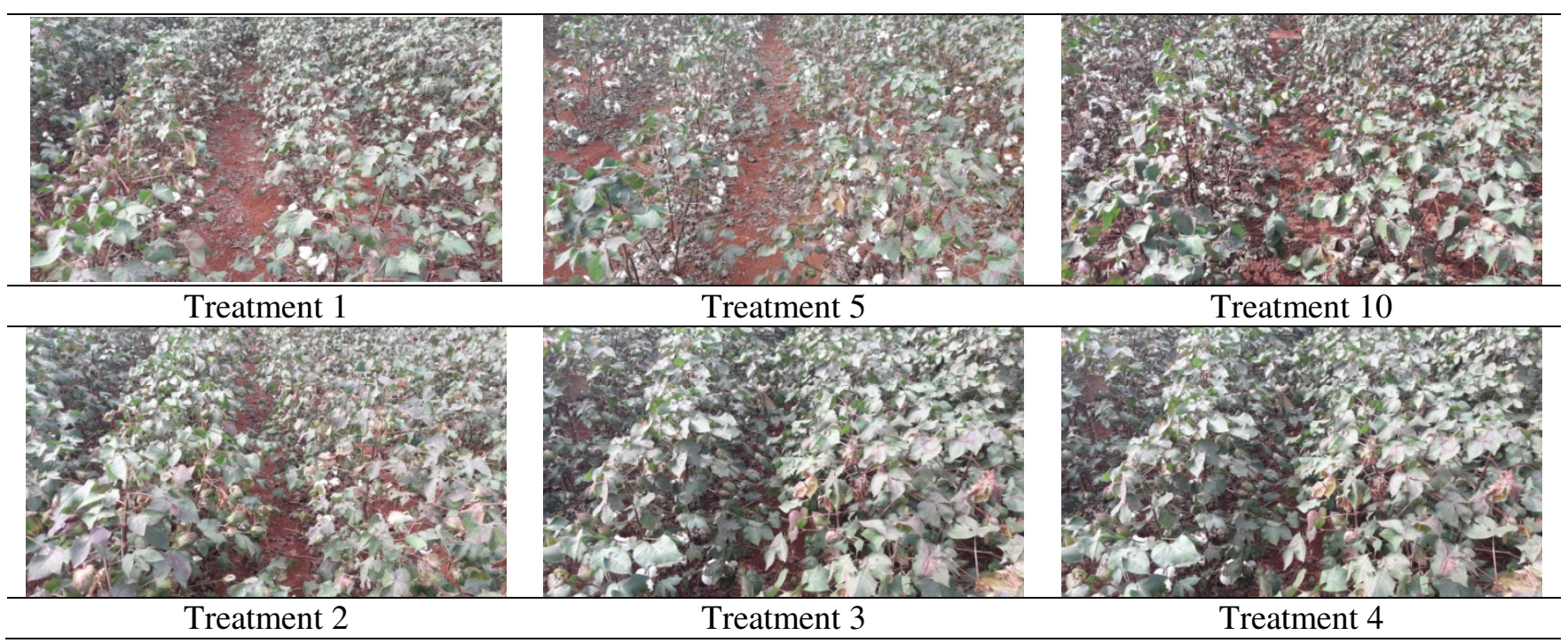

Figure 1. Images of the treatments with greater defoliation due to ramularia leaf spot at the $\mathrm{C} 3$ stage. 
Table 2 shows a significant difference between the treatments used for the indices NDVI S, NDVI GS, SAVI-R 1, SAVI-R 2, and SR-R. Treatments 2, 3, 4, 6, 8, 9, 11, and 17 resulted in the highest means for NDVI S. Treatments 2, 3, 4, 6, 9, 11, and 17 allowed the highest means for SAVI 1 and SAVI 2. Finally, treatments 2, 3, 4, 6, 9, and 17 provided the highest means for SR-R.
MARTINS, L. M. et al.

Based on these data, the high values of the vegetation indices suggest that treatments with the highest amount of leaves per unit area might have undergone less disease attack, resulting in a higher yield. Dissimilarities between vegetation indices can be explained by the different way of calculating them or by the different way of collecting data, and the results of each vegetation index may be more usable depending on the purpose.

Table 2. Summary of the analysis of variance for the variables NDVI S, NDVI GS, SAVI-R 1, SAVI-R 2, and SR-R evaluated in cotton under different fungicides for ramularia leaf spot control.

\begin{tabular}{lccccc}
\hline Treatment & NDVI S & NDVI GS & SAVI-R 1 & SAVI-R2 & SR R \\
\hline 1 & & & & $0.66 \mathrm{~b}$ & $11.58 \mathrm{~b}$ \\
2 & $0.84 \mathrm{~b}$ & $0.71 \mathrm{a}$ & $0.55 \mathrm{~b}$ & $0.73 \mathrm{a}$ & $15.77 \mathrm{a}$ \\
3 & $0.88 \mathrm{a}$ & $0.75 \mathrm{a}$ & $0.61 \mathrm{a}$ & $0.74 \mathrm{a}$ & $15.24 \mathrm{a}$ \\
4 & $0.87 \mathrm{a}$ & $0.77 \mathrm{a}$ & $0.62 \mathrm{a}$ & $0.74 \mathrm{a}$ & $15.49 \mathrm{a}$ \\
5 & $0.88 \mathrm{a}$ & $0.78 \mathrm{a}$ & $0.62 \mathrm{a}$ & $0.67 \mathrm{~b}$ & $12.80 \mathrm{~b}$ \\
6 & $0.84 \mathrm{~b}$ & $0.72 \mathrm{a}$ & $0.56 \mathrm{~b}$ & $0.73 \mathrm{a}$ & $15.02 \mathrm{a}$ \\
7 & $0.87 \mathrm{a}$ & $0.76 \mathrm{a}$ & $0.61 \mathrm{a}$ & $0.67 \mathrm{~b}$ & $12.09 \mathrm{~b}$ \\
8 & $0.84 \mathrm{~b}$ & $0.74 \mathrm{a}$ & $0.56 \mathrm{~b}$ & $0.69 \mathrm{~b}$ & $13.68 \mathrm{~b}$ \\
9 & $0.86 \mathrm{a}$ & $0.76 \mathrm{a}$ & $0.58 \mathrm{~b}$ & $0.73 \mathrm{a}$ & $16.01 \mathrm{a}$ \\
& $0.87 \mathrm{a}$ & $0.78 \mathrm{a}$ & $0.61 \mathrm{a}$ & & \\
10 & & & $0.55 \mathrm{~b}$ & $0.66 \mathrm{~b}$ & $11.35 \mathrm{~b}$ \\
11 & $0.83 \mathrm{~b}$ & $0.72 \mathrm{a}$ & $0.61 \mathrm{a}$ & $0.73 \mathrm{a}$ & $13.58 \mathrm{~b}$ \\
12 & $0.86 \mathrm{a}$ & $0.75 \mathrm{a}$ & $0.56 \mathrm{~b}$ & $0.68 \mathrm{~b}$ & $11.92 \mathrm{~b}$ \\
13 & $0.84 \mathrm{~b}$ & $0.75 \mathrm{a}$ & $0.59 \mathrm{~b}$ & $0.70 \mathrm{~b}$ & $12.76 \mathrm{~b}$ \\
14 & $0.85 \mathrm{~b}$ & $0.73 \mathrm{a}$ & $0.57 \mathrm{~b}$ & $0.68 \mathrm{~b}$ & $12.23 \mathrm{~b}$ \\
15 & $0.85 \mathrm{~b}$ & $0.73 \mathrm{a}$ & $0.56 \mathrm{~b}$ & $0.68 \mathrm{~b}$ & $12.06 \mathrm{~b}$ \\
16 & $0.84 \mathrm{~b}$ & $0.72 \mathrm{a}$ & $0.56 \mathrm{~b}$ & $0.67 \mathrm{~b}$ & $11.59 \mathrm{~b}$ \\
17 & $0.84 \mathrm{~b}$ & $0.76 \mathrm{a}$ & $0.61 \mathrm{a}$ & $0.73 \mathrm{a}$ & $14.35 \mathrm{a}$ \\
\hline Mean & $0.87 \mathrm{a}$ & $0.77 \mathrm{a}$ & 0.58 & 0.70 & 13.38 \\
F-calculated & 0.85 & 0.75 & $2.93^{*}$ & $2.93^{*}$ & $3.16^{*}$ \\
CV $(\%)$ & $2.10^{*}$ & $1.52 \mathrm{~ns}$ & 5.04 & 5.04 & 13.71 \\
\hline
\end{tabular}

*: significant at $5 \%$ probability by the $\mathrm{F}$ test; $\mathrm{CV}$ : coefficient of variation.

Table 2 shows that the coefficient of variation $(\mathrm{CV} \%)$ was low for all the indices, with the highest values recorded for SR-R. This low CV value between the indices can explain its low expression in relation to ramularia leaf spot effects.

Table 3 shows a significant difference between the treatments used for the variables
NDRE, SAVI-RE 2, and SR-RE. Treatments 2, 3, 4, $6,9,11,13,14$, and 17 provided the highest means for NDRE. Treatments 2, 3, 4, 6, 9, 11, and 17 showed the highest means for SAVI-RE 2. Treatments 2, 3, 4, 6, 9, and 17 had the highest means for SR-RE.

Table 3. Summary of the analysis of variance for the variables NDRE, SAVI-RE 1, SAVI-RE 2, and SR-RE evaluated in cotton under different fungicides for ramularia leaf spot control.

\begin{tabular}{lcccc}
\hline Treatment & NDRE & SAVI-RE 1 & SAVI-RE 2 & SR RE \\
\hline 1 & $0.10 \mathrm{~b}$ & $0.08 \mathrm{a}$ & $0.10 \mathrm{~b}$ & $1.23 \mathrm{~b}$ \\
2 & $0.13 \mathrm{a}$ & $0.11 \mathrm{a}$ & $0.13 \mathrm{a}$ & $1.30 \mathrm{a}$ \\
3 & $0.12 \mathrm{a}$ & $0.10 \mathrm{a}$ & $0.12 \mathrm{a}$ & $1.27 \mathrm{a}$ \\
4 & $0.13 \mathrm{a}$ & $0.11 \mathrm{a}$ & $0.13 \mathrm{a}$ & $1.30 \mathrm{a}$ \\
5 & $0.07 \mathrm{~b}$ & $0.06 \mathrm{a}$ & $0.07 \mathrm{~b}$ & $1.19 \mathrm{~b}$ \\
6 & $0.12 \mathrm{a}$ & $0.10 \mathrm{a}$ & $0.12 \mathrm{a}$ & $1.27 \mathrm{a}$ \\
7 & $0.10 \mathrm{~b}$ & $0.08 \mathrm{a}$ & $0.10 \mathrm{~b}$ & $1.23 \mathrm{~b}$
\end{tabular}




\begin{tabular}{lcccc}
8 & $0.09 \mathrm{~b}$ & $0.10 \mathrm{a}$ & $0.09 \mathrm{~b}$ & $1.20 \mathrm{~b}$ \\
9 & $0.12 \mathrm{a}$ & $0.11 \mathrm{a}$ & $0.12 \mathrm{a}$ & $1.27 \mathrm{a}$ \\
10 & $0.09 \mathrm{~b}$ & $0.07 \mathrm{a}$ & $0.08 \mathrm{~b}$ & $1.19 \mathrm{~b}$ \\
11 & $0.10 \mathrm{a}$ & $0.09 \mathrm{a}$ & $0.11 \mathrm{a}$ & $1.24 \mathrm{~b}$ \\
12 & $0.09 \mathrm{~b}$ & $0.08 \mathrm{a}$ & $0.09 \mathrm{~b}$ & $1.21 \mathrm{~b}$ \\
13 & $0.10 \mathrm{a}$ & $0.08 \mathrm{a}$ & $0.10 \mathrm{~b}$ & $1.22 \mathrm{~b}$ \\
14 & $0.11 \mathrm{a}$ & $0.09 \mathrm{a}$ & $0.10 \mathrm{~b}$ & $1.24 \mathrm{~b}$ \\
15 & $0.09 \mathrm{~b}$ & $0.07 \mathrm{a}$ & $0.09 \mathrm{~b}$ & $1.20 \mathrm{~b}$ \\
16 & $0.09 \mathrm{~b}$ & $0.07 \mathrm{a}$ & $0.09 \mathrm{~b}$ & $1.26 \mathrm{a}$ \\
17 & $0.11 \mathrm{a}$ & $0.10 \mathrm{a}$ & $0.12 \mathrm{a}$ & 1.24 \\
\hline Mean & 0.10 & 0.09 & 0.10 & $2.17 *$ \\
F-calculated & $2.16^{*}$ & $1.86 \mathrm{~ns}$ & $2.42^{*}$ & 3.97 \\
CV $(\%)$ & 20.23 & 24.91 & 21.77 & \\
\hline
\end{tabular}

*: significant at $5 \%$ probability by the $\mathrm{F}$ test; $\mathrm{CV}$ : coefficient of variation.

Table 3 indicates that the CV values for the indices calculated with the Red Edge band were higher than those calculated with the Red band. SAVI-RE 2 presented greater sensitivity in recording leaves infected with ramularia leaf spot.

Meanwhile, Table 4 demonstrates a significant difference between the treatments used for all variables. Treatments $3,4,8$, and 9 provided the highest means for PH. Treatments 3, 4, and 6 had the highest means for YIE in arrobas $\mathrm{ha}^{-1}$ of cotton seed, whose values were also higher for all vegetation indices and EF. Treatment 1 provided the highest mean for AUDPC (control) and had the greatest amount of disease over the crop cycle. This result is for the treatment did not receive any fungicide. For those that received some fungicide, treatments 5, 7, 8, and 16 showed less disease control, i.e., they presented higher AUDPC means. This result proves that these treatments had the least disease control with eight sequential applications. For EF, treatments 2, 3, 4, 6, 9, 11, and 17 presented the highest means and provided the best performance for disease control.

Table 4. Summary of analysis of variance for plant height (PH), seed cotton yield (YIE), area under the disease progress curve (AUDPC), and agronomic efficiency (EF) evaluated in cotton under different fungicides for ramularia leaf spot control.

\begin{tabular}{lcccc}
\hline Treatment & PH $(\mathrm{m})$ & YIE @/ha & AUDPC & EF \\
\hline 1 & $0.99 \mathrm{~b}$ & $332.75 \mathrm{~d}$ & $1204.31 \mathrm{a}$ & $0.10 \mathrm{e}$ \\
2 & $0.99 \mathrm{~b}$ & $363.75 \mathrm{c}$ & $14.38 \mathrm{e}$ & $0.99 \mathrm{a}$ \\
3 & $1.05 \mathrm{a}$ & $414.72 \mathrm{a}$ & $22.13 \mathrm{e}$ & $0.98 \mathrm{a}$ \\
4 & $1.05 \mathrm{a}$ & $393.19 \mathrm{a}$ & $84.88 \mathrm{e}$ & $0.94 \mathrm{a}$ \\
5 & $1.00 \mathrm{~b}$ & $325.94 \mathrm{~d}$ & $738.00 \mathrm{~b}$ & $0.45 \mathrm{~d}$ \\
6 & $1.00 \mathrm{~b}$ & $401.25 \mathrm{a}$ & $101.13 \mathrm{e}$ & $0.92 \mathrm{a}$ \\
7 & $1.01 \mathrm{~b}$ & $370.81 \mathrm{~b}$ & $745.50 \mathrm{~b}$ & $0.44 \mathrm{~d}$ \\
8 & $1.05 \mathrm{a}$ & $375.00 \mathrm{~b}$ & $753.50 \mathrm{~b}$ & $0.44 \mathrm{~d}$ \\
9 & $1.05 \mathrm{a}$ & $358.06 \mathrm{c}$ & $66.88 \mathrm{e}$ & $0.95 \mathrm{a}$ \\
10 & $0.92 \mathrm{~b}$ & $351.33 \mathrm{c}$ & $505.25 \mathrm{c}$ & $0.62 \mathrm{c}$ \\
11 & $0.98 \mathrm{~b}$ & $384.67 \mathrm{~b}$ & $33.44 \mathrm{e}$ & $0.98 \mathrm{a}$ \\
12 & $0.92 \mathrm{~b}$ & $338.06 \mathrm{~d}$ & $293.75 \mathrm{~d}$ & $0.78 \mathrm{~b}$ \\
13 & $1.01 \mathrm{~b}$ & $348.89 \mathrm{c}$ & $447.75 \mathrm{c}$ & $0.67 \mathrm{c}$ \\
14 & $0.96 \mathrm{~b}$ & $333.33 \mathrm{~d}$ & $361.75 \mathrm{~d}$ & $0.73 \mathrm{~b}$ \\
15 & $0.97 \mathrm{~b}$ & $345.83 \mathrm{c}$ & $587.75 \mathrm{c}$ & $0.56 \mathrm{c}$ \\
16 & $0.98 \mathrm{~b}$ & $332.31 \mathrm{~d}$ & $826.63 \mathrm{~b}$ & $0.38 \mathrm{~d}$ \\
17 & $0.99 \mathrm{~b}$ & $374.42 \mathrm{~b}$ & $76.38 \mathrm{e}$ & $0.94 \mathrm{a}$ \\
\hline Mean & 0.99 & 361.43 & 403.73 & 0.70 \\
F-calculated & $2.01^{*}$ & $9.63^{*}$ & $38.26 *$ & $38.24^{*}$ \\
CV (\%) & 5.78 & 4.72 & 28.89 & 12.46 \\
\hline
\end{tabular}

*: significant at $5 \%$ probability by the $\mathrm{F}$ test; $\mathrm{CV}$ : Coefficient of variation. 
Over the crop development, treatments 2, 5, and 11 showed phytotoxicity symptoms (05/08/2017) at the C1 phenological stage after the last fungicide application (05/05/2017). Symptoms consisted of reddish color leaves, mostly on the adaxial side, near the edge. However, they probably did not affect the vegetation index, as the values of

The most relevant data may be revealed by comparing the treatments that had the highest values in practically all the vegetation indices shown in Tables 2 and 3, i.e., treatments 2, 3, 4, 6, 9, 11, and 17. These treatments also presented the lowest AUDPC values, as shown in Table 4. The present these plots were consistent with those of EF (Table 2, 3, and 4). Conversely, a great variation was observed for yield, which was reduced in all the plots with phytotoxicity symptom, promoted by the abortion of the crowns in the upper third of the plants.

result corroborates those for NDVI S, NDRE, SAVI-R 1, SAVI-R 2, and SAVI-RE 2, which are sensitive for detecting the treatments able to control the disease, where the most sensitive indices are the most correlated to AUDPC (Figure 2).

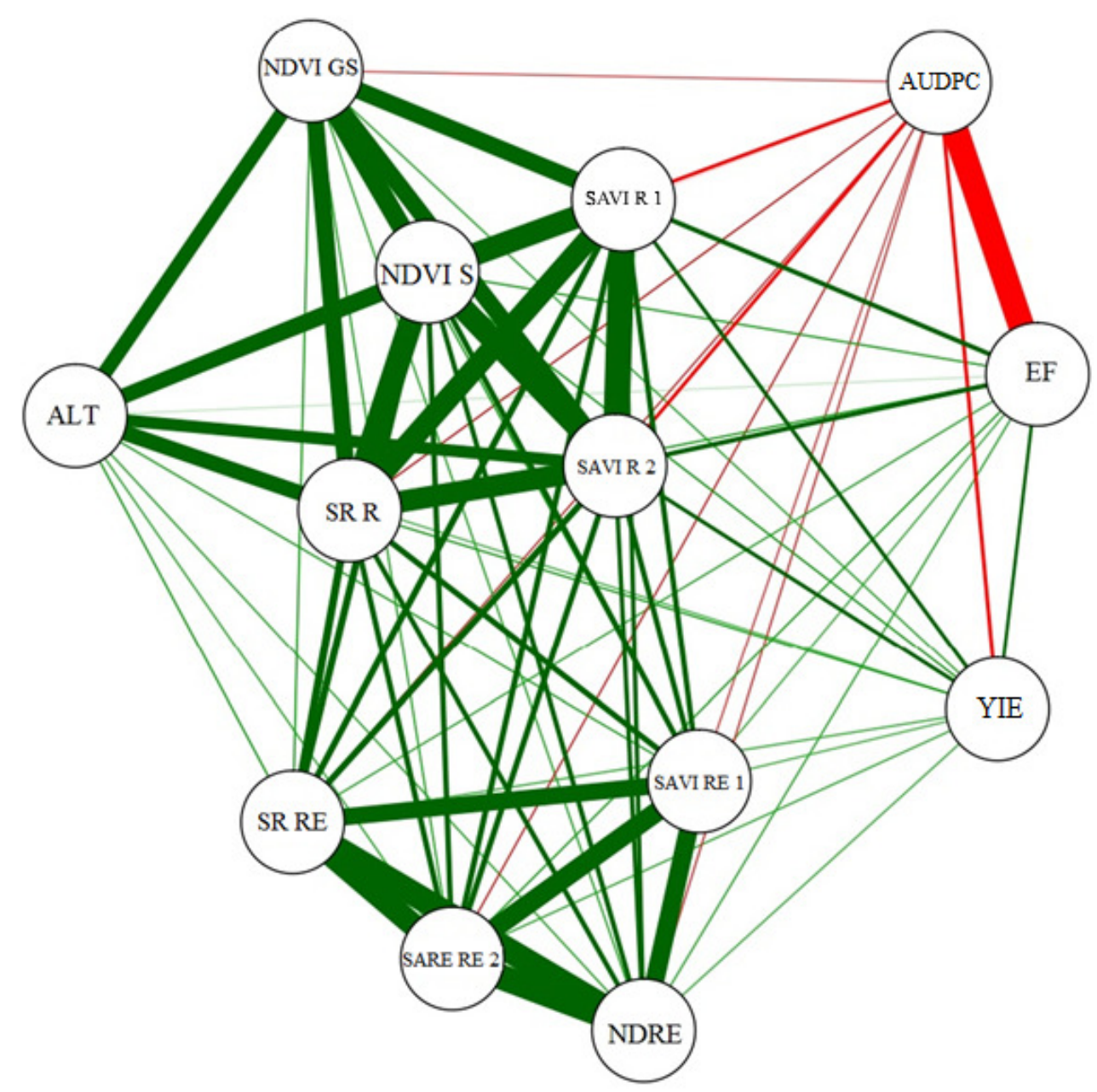

Figure 2. Pearson's correlation network between the evaluated variables.

The values of the Pearson's correlation network shown in Figure 2 ranged between 0 and 1 for green trace and between -1 and 0 for red trace. The trace thickness corresponds to the magnitude of its correlation. All correlations of AUDPC showed red color traces, indicating that this variable presented values inversely proportional to those of the other variables, and the higher the AUDPC, the lower was the control action of the fungicide.
Figure 2 shows a strong negative correlation between AUDPC and EF since the higher the efficiency value, the greater was the fungicide action and the lower was the disease severity (AUDPC). EF showed a positive relationship with yield and was not higher due to the phytotoxicity caused by some products. Conversely, AUDPC presented an inverse relationship with yield, as expected. 
Bergamin Filho et al. (1995), when evaluating foliar diseases of common bean, observed no correlation between yield and AUDPC, whereas the present study revealed a strong correlation. This result proved the relevance of the study on ramularia leaf spot since the difference between the control and the most productive treatment is of 81.97 arrobas ha ${ }^{-1}$ of cotton seed. The products with higher disease control potential did not necessarily present the highest yields owing to their higher phytotoxicity.

The vegetation indices SAVI-R 1 and SAVI-R 2 were the most correlated to EF and YIE and presented the highest negative correlation to AUDPC. Cao et al. (2013) obtained similar results and found a significant correlation between SAVI and wheat disease severity index. This result indicates that this vegetation index can detect disease in an area, but is still not very sensitive to show the disease severity. This fact is because low efficiency leads to non-significant differences in SAVI 1, even being lower. The vegetation indices SAVI-RE 1 and SAVI-RE 2 showed a weak positive correlation to YIE and EF, evidencing that the Red spectral range for this vegetation index is more sensitive than the Red Edge range.

NDVI $S$ and NDVI GS showed a strong positive correlation to $\mathrm{PH}$, which did not present this same correlation to YIE and EF. NDRE had a low correlation to EF and YIE; however, it was higher than that of NDVIs. SR-R, SR-RE, and NDVIs had a higher correlation to PH than YIE.

\section{CONCLUSIONS}

The vegetation indices NDVI and SR $R$ showed a higher correlation to plant height when compared with the other agronomic indices.

SAVI, obtained with the wavelength in the Red spectral range, presented a higher correlation to efficiency and yield, being the most expressive index for ramularia leaf spot effects.

The vegetation indices that used the wavelength values in the Red spectral range showed a higher correlation to plant height, yield, and efficiency when compared with those that used values of wavelength in the Red Edge spectral range.

RESUMO: Este trabalho objetivou correlacionar diferentes índices de vegetação em resposta aos efeitos causados pela mancha de ramulária (Ramularia areola) de vários tratamentos com produtos fungicidas. O experimento foi implantado no município de Chapadão do Sul, Estado de Mato Grosso do Sul, no ano agrícola 2016/2017. O delineamento experimental utilizado foi blocos casualizados com 17 tratamentos com quatro repetições. Foram obtidos dados a partir do sensor passivo Sequoia 4.0 e do sensor ativo Green Seeker LT 200. A partir das informações registradas pelos sensores, foram gerados nove índices de vegetação, que foram comparados com a área abaixo da curva de progresso da doença, altura de plantas, produtividade e eficiência agronômica em 17 diferentes tratamentos de produtos de ação fungicida. Os tratamentos responderam de forma distinta em relação ao produto neles aplicados, sendo que os índices SAVI (Soil Adjusted Vegetation Index), obtidos a partir da banda na faixa espectral do Red, apresentaram maior correlação com AACPD, eficiência e produtividade. Já o índice NDVI (Normalized Difference Vegetation Index) obteve maior correlação com a altura de plantas e SR (Simple Ratio), ambos utilizando o comprimento de onda na faixa espectral da banda Red.

PALAVRAS-CHAVE: Gossypium hirsutum L. Doenças do algodoeiro. Sensoriamento remoto. Sensores multiespectrais.

\section{REFERENCES}

ABBOTT, W. S. A method of computing the effectiveness of an inseticide. Journal of Economic

Entomology, College Park, v. 18, n. 1, p. 265-267, 1925. https://doi.org/10.1093/jee/18.2.265a

AHAMED, T.; TIAN, L.; ZHANG, Y.; TING, K. C. A review of remote sensing methods for biomass feedstock production. Biomass and Bioenergy, Amsterdã, v. 35, p. 2455-2469, 2011.

AQUINO, L. A. Elaboração e validação de escala diagramática para quantificação da mancha de ramularia do algodoeiro. Summa Phytopathologica, Botucatu, v. 34, p. 361-363, 2008.

BERGAMIN FILHO, A.; LOPES, D. B.; AMORIM, L.; GODOY, C. V.; BERGER, R. D. Avaliação de danos causados por doenças de plantas. Revisão Anual de Patologia de Plantas, São Paulo, p. 133-170, 1995. 
BHERING, L. L. Rbio: A Tool For Biometric And Statistical Analysis Using The R Platform. Crop Breeding and Applied Biotechnology, Viçosa, v. 17, p. 187-190, 2017.

CAO, X.; LUO, Y.; ZHOU, Y.; DUAN, X.; CHENG, D. Detection of powdery mildew in two winter wheat cultivars using canopy hyperspectral reflectance. Crop Protection, Amsterdã, v. 45, p.124-131, 2013.

DEVADAS, R.; LAMB, D. W.; SIMPFENDORFER, S.; BACKHOUSE, D. Evaluating ten spectral vegetation indices for identifying rust infection in individual wheat leaves. Precision Agriculture, Amsterdã, v. 10, p. 459-470, 2009.

FRENCH, A. N.; HUNSAKER, D. J.; THORP, K. R. Remote sensing of evapotranspiration over cotton using the TSEB and METRIC energy balance models. Remote Sensing of Environment, Amsterdã, v. 158, p. 281294, 2015.

GALBIERI, R.; CIA, E.; MORELLO, C. D. L.; FANAN, S.; JUNIOR, A.; RICARDO, E.; KOBAYASTI, L. Ramularia areola sporulation potential in Brazilian cotton. Summa Phytopathologica, v. 41, n. 3, p. 233-235, 2015.

GIROTTO, L.; MARANGONI, M. S.; MATOS, J. N.; GALBIERI, R.; ALMEIDA, W. P.; MEHTA, Y. R. Identification of phenotypic and genotypic variability among the isolates of Ramularia areola of Brazilian Cotton. American Journal of Plant Sciences, Wuhan, v. 4, n. 09, p. 1893, 2013.

https://doi.org/10.4236/ajps.2013.49232

GONZÁLEZ-DUGO, M. P.; MATEOS, L. Spectral vegetation indices for benchmarking water productivity of irrigated cotton and sugarbeet crops. Agricultural water management, Amsterdã, v. 95, n. 1, p. 48-58, 2008.

HUETE, A. R. A soil-adjusted vegetation index (SAVI). Remote Sensing of Environment, Amsterdão, v. 25, n. 3, p. 295-309, 1988.

HUNSAKER, D. J.; PINTER, P. J.; BARNES, E. M.; KIMBALL, B. A. Estimating cotton evapotranspiration crop coefficients with a multispectral vegetation index. Irrigation science, Madison, v. 22, n. 2, p. 95-104, 2003.

PONZONI, F. J.; SHIMABUKURO, Y. E.; KUPLICH, T. M. Sensoriamento remoto da vegetação. 2. Ed. atualizada e ampliada, São Paulo, SP, oficina de textos, p86, 2012.

SHIVANKAR, S. K.; WANGIKAR, P. D. Estimation of crop losses due to grey mildew disease of cotton caused by Ramularia areola. Indian Phytopathology, New Delhi, v. 45, n. 1, p. 74-76, 1992.

QI, J.; CHEHBOUNI, A.; HUETE, A. R.; KERR. Y. H.; Sorooshian, S. A modified soil adjusted vegetation index. Remote sensing of environment, v. 48, n. 2, p. 119-126, 1994. https://doi.org/10.1016/00344257(94)90134-1

ZARCO-TEJADA, P. J.; USTIN, S. L.; WHITING, M. L. Temporal and spatial relationships between withinfield yield variability in cotton and high-spatial hyperspectral remote sensing imagery. Agronomy Journal, Madison, v. 97, n. 3, p. 641-653, 2005. https://doi.org/10.2134/agronj2003.0257 